\title{
3' terminal diversity of MRP RNA and other human noncoding RNAs revealed by deep sequencing
}

\author{
Katherine C Goldfarb ${ }^{1}$ and Thomas R Cech ${ }^{1,2^{*}}$
}

\begin{abstract}
Background: Post-transcriptional 3' end processing is a key component of RNA regulation. The abundant and essential RNA subunit of RNase MRP has been proposed to function in three distinct cellular compartments and therefore may utilize this mode of regulation. Here we employ 3' RACE coupled with high-throughput sequencing to characterize the $3^{\prime}$ terminal sequences of human MRP RNA and other noncoding RNAs that form RNP complexes.

Results: The 3' terminal sequence of MRP RNA from HEK293T cells has a distinctive distribution of genomically encoded termini (including an assortment of $U$ residues) with a portion of these selectively tagged by oligo(A) tails. This profile contrasts with the relatively homogenous $3^{\prime}$ terminus of an in vitro transcribed MRP RNA control and the differing 3' terminal profiles of U3 snoRNA, RNase P RNA, and telomerase RNA (hTR).

Conclusions: 3' RACE coupled with deep sequencing provides a valuable framework for the functional characterization of $3^{\prime}$ terminal sequences of noncoding RNAs.
\end{abstract}

Keywords: RNase MRP RNA, 3' RACE deep sequencing, Oligo(U), Oligo(A), Telomerase RNA

\section{Background}

The addition of non-templated nucleotides to the $3^{\prime}$ ends of RNA molecules is a widespread mechanism for their regulation. Beyond the familiar long poly(A) tails of messenger RNAs, short 3' tailing of uridine [1-4] and adenosine [5-7] nucleotides to noncoding RNAs is gathering increasing appreciation. These simple oligonucleotide additions (one to $\sim 20$ identical bases) can alter the stability, binding partners or activity of the enzymatic reactions in which these RNAs participate. Further, many of these 3' terminally extended noncoding RNAs, including U6 spliceosomal RNA [8], tRNAs [4] and several snoRNAs $[9,10]$, have annotated termini flanked by a stretch of genomically encoded U's. The detailed interplay of transcriptional termination, trimming and post-transcriptional oligonucleotide addition has been elegantly characterized for a few systems [11], but the precise 3 ' processing

\footnotetext{
* Correspondence: thomas.cech@colorado.edu

'Department of Chemistry and Biochemistry, BioFrontiers Institute, University of Colorado, Boulder, CO, USA

${ }^{2}$ Howard Hughes Medical Institute, University of Colorado, Boulder, CO, USA
}

cascade and functional termini for many other critical noncoding RNAs remain unclear.

RNase MRP is a ribonucleoprotein complex with a single RNA component (MRP RNA) transcribed by RNA polymerase III [12]. Mutation of the sole MRP RNA genomic locus results in inviable yeast [13] and a spectrum of pleiotropic human diseases [14], supporting the assertion that MRP RNA is essential to eukaryotic life. In association with at least 10 proteins in humans $[15,16]$, MRP RNA is implicated in the specific endoribonucleolytic cleavage $[17,18]$ of several vital RNA substrates [19-24] found in the nucleolus [25,26], cytoplasm [24,27] and possibly mitochondria $[28,29]$ of the eukaryotic cell. All of the MRP proteins also associate with the RNase P RNA [15,30] to form the enzyme responsible for the cleavage of tRNA 5' leader sequences. Thus, RNase MRP requires tight regulation to discern its proper RNA subunit and cleave its many substrates.

Because 3 ' end processing is a prevalent and potent means of regulation for other noncoding RNAs and because one instance of dramatic 3' extension of MRP RNA was previously reported [31], we sought to

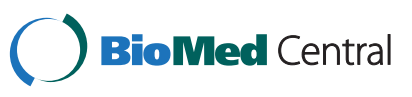

(c) 2013 Goldfarb and Cech; licensee BioMed Central Ltd. This is an Open Access article distributed under the terms of the Creative Commons Attribution License (http://creativecommons.org/licenses/by/2.0), which permits unrestricted use, distribution, and reproduction in any medium, provided the original work is properly cited. 
thoroughly examine the 3' ends of MRP RNA present in human cells. Combining aspects of various protocols [32-34], we employed a modified 3' RACE with deep sequencing protocol and found a distribution of genomically encoded 3' ends including variable U's beyond the annotated 3 ' nucleotide. Modest oligo(A) addition was also observed, particularly after more than one uridine. This profile contrasted with distinct distributions of U's and A's on other noncoding RNAs and the relatively homogenous 3 ' terminus of an in vitro transcribed control MRP RNA.

\section{Results}

To comprehensively define the 3 '-hydroxyl ends of endogenous RNA molecules in HEK293T cells, we adapted an RNA ligase-mediated 3' RACE strategy coupled to deep sequencing (Figure 1). While similar methods have been previously reported [33], our protocol incorporated a few modifications. Precise 3 ' terminal nucleotides were demarcated by ligation of whole cell RNA preparations

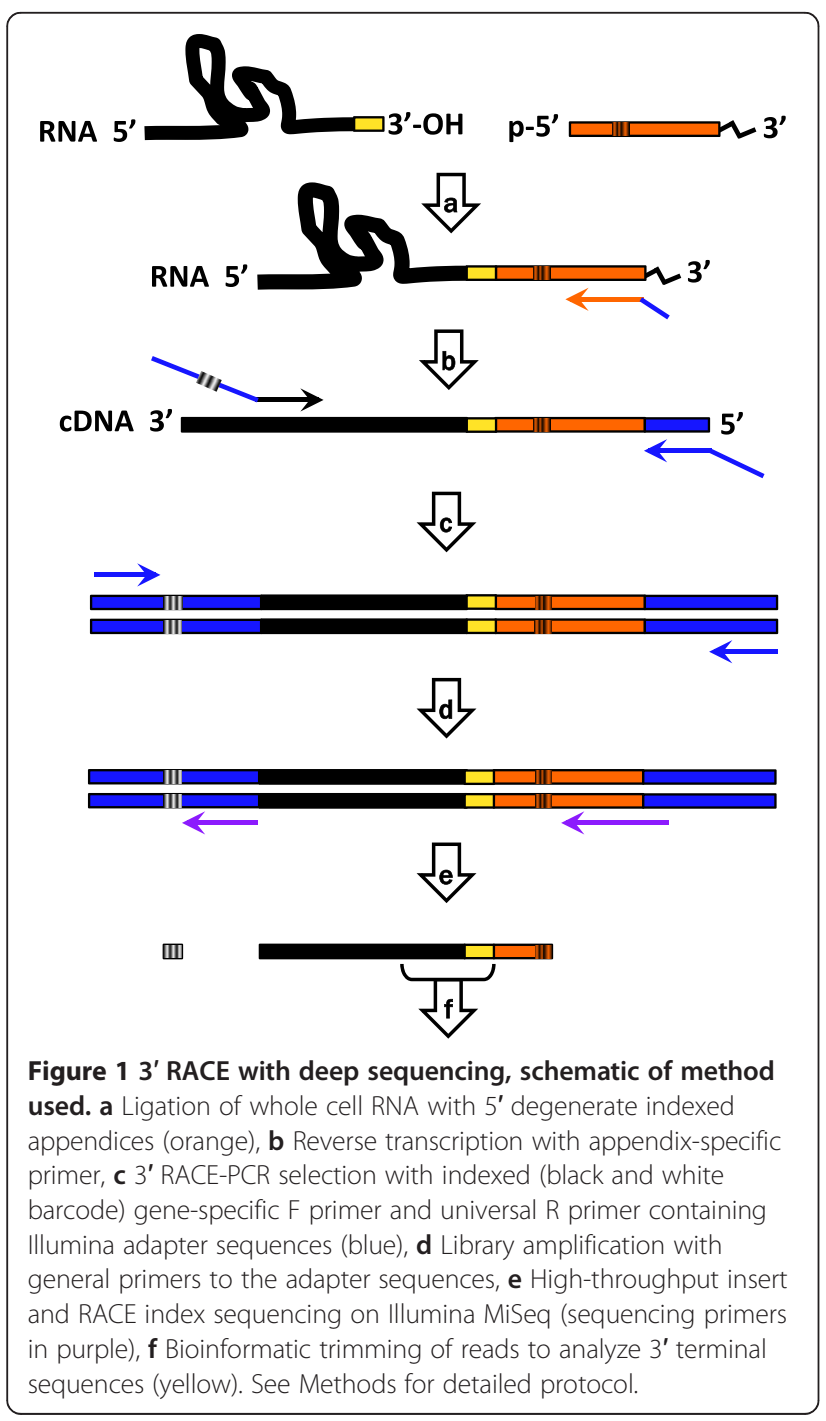

with four distinct oligoribonucleotide appendices, each containing a different $5^{\prime}$ terminal base and internal barcode to minimize structural bias during this reaction [32,35]. Further, to ensure signal from low abundance RNA species, a library amplification step was included after the RACE selection [34].

We obtained an average of 955,000 trimmed reads (range of 53,997 - 2,235,651 for 6 libraries, see Methods) per experiment for endogenous MRP RNA. Unlike typical pipelines, alignment of sequences to the reference genome was not performed, since this would have eliminated detection of extensions not mapping to the genomic template. Instead, raw sequencing reads were filtered to obtain a rigorous set where each read contained both a 3 ' region of MRP RNA (Additional file 1: Table S1) and one of the appendix oligonucleotides. Since our focus was 3' extension, reads displaying RNA termini truncated upstream of the annotated $3^{\prime}$ end were excluded by this analysis.

Endogenous MRP RNA molecules displayed a distinctive profile of 3' ends. While the majority of these termini mapped to the RMRP gene locus (Figure 2a, upper panel), we observed a clear preference in this cell type for one previously annotated end (...CUGU, $\sim 62 \%$ ) over another (...CU, 1\%). Additional uridines beyond these ends were also detected; these may arise from primary transcriptional termination beyond the annotated end, or posttranscriptional oligouridylation by 3 ' uridyltransferases [36]. While these possible mechanisms cannot be distinguished by our methods, the apparent greater propensity for four or five uridines presumably indicates these endings are more frequently generated or are more stable species in this cell type. Among the $~ 9 \%$ fraction of 3 ' ends that failed complete alignment to the genomic template, most were additions of adenosines to genomically encoded termini. Interestingly, these A's were most likely to appear after multiple U's (Figure 2b, upper panel), suggesting different 3 ' ends have distinct propensities for the addition of oligo(A) tails. Our observation that various lengths of oligo(U) are often followed by an A, but the A termini are not followed by U's, was noted previously for signal recognition particle RNA, 7SK RNA, 5S rRNA and U6 snRNA [5]. To test whether the observed MRP RNA 3 ' ends were specific to the cell line tested, we sequenced MRP RNA from a second human cell line (K562) and found it to display similar genomically encoded and oligo(A) termini (Additional file 2: Figure S1).

To control for the possibility that our library preparation method could contribute to this profile of 3' ends, we constructed a barcoded in vitro transcript of MRP RNA (ivt-MRP), spiked it into our cellular RNA, and prepared a single library for deep sequencing. The template for ivt-MRP was designed to have the commonly annotated ...CU 3' end produced by run-off transcription. As expected for this template, and in contrast 


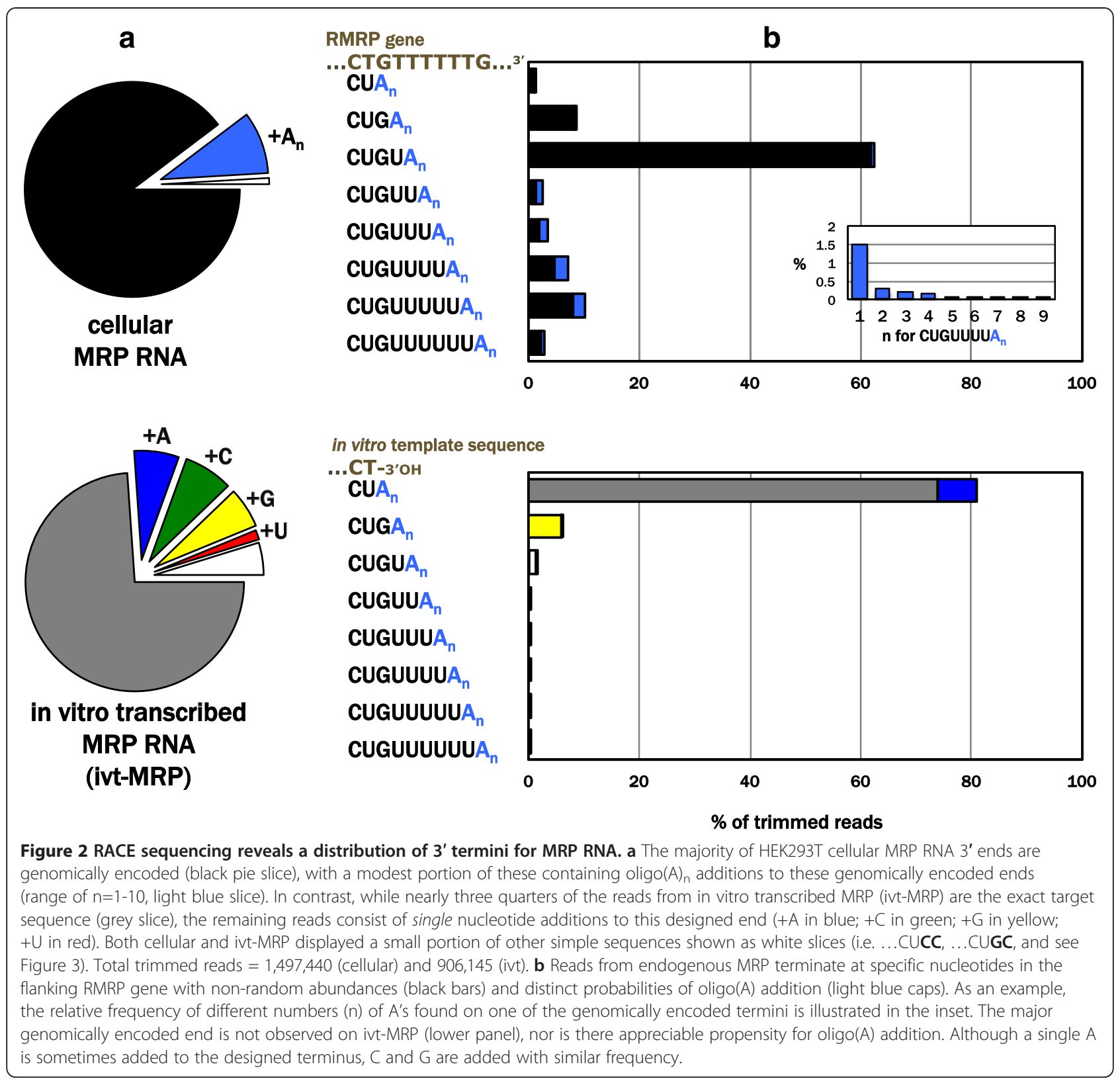

to endogenous MRP RNA, ivt-MRP showed no appreciable abundance of the ...CUGU ending nor a penchant for additional U's or A's (Figure 2b). Rather, 95\% of the ivt-MRP ends represented the designed terminus (...CU, $\sim 75 \%$ ) or single nucleotide additions to this terminus in which each base had a comparable propensity for incorporation (Figure $2 \mathrm{a}$, lower panel). The number of reads for indexed ivt-MRP relative to endogenous MRP in the control libraries closely matched the expected ratio, based on northern hybridization (Additional file 3: Figure S2). Thus, the relative number of sequencing reads appears to correlate with relative RNA abundance in the library. Combined with the absence of multiple U's or oligo(A) additions on ivt-MRP, this argues that the presence of these endings on the endogenous RNA directly reflects the MRP termini in vivo.

About $1 \%$ of ivt-MRP endings were strikingly complex (Figure 3a). These extensions beyond the designed 3' end were complementary to nearby regions of the MRP RNA sequence (Figure 3b). An attractive mechanism for generation of these observed termini is $3^{\prime}$ end loopback or duplex RNA-dependent RNA polymerase extension by T7 RNA polymerase [37] analogous to that observed for mouse B2 RNA by RNA polymerase II [38]. The three examples shown demonstrate distinct registers of 3 ' end loopback that would explain the observed extension sequences. Because such complex termini were conspicuously present only on ivt-MRP when compared 


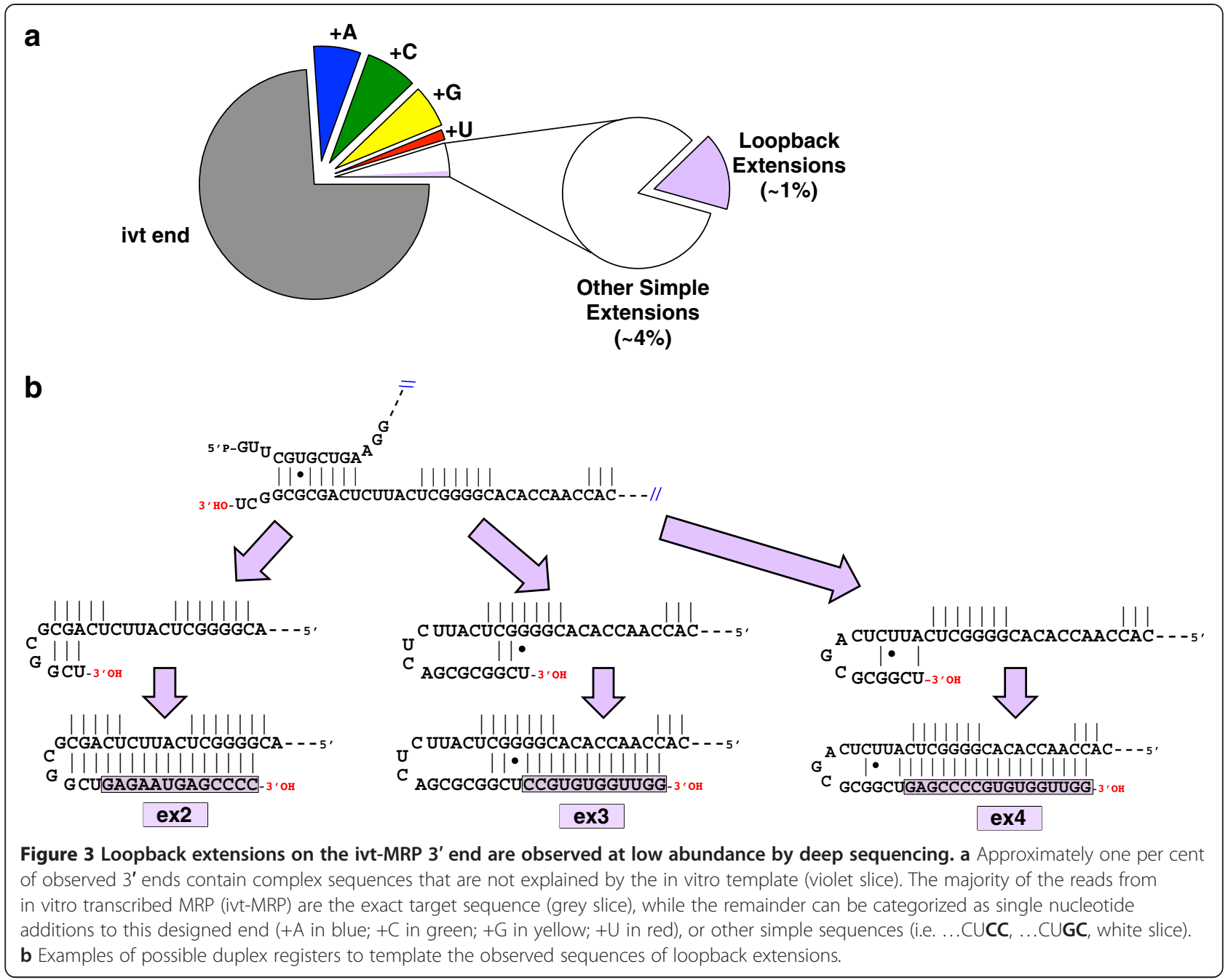

directly with endogenous MRP, we conclude that these complex 3' termini were likely to have been produced during $\mathrm{T} 7$ transcription and then faithfully retained through library preparation and sequencing.

One key advantage to this $3^{\prime}$ RACE sequencing method is the transcriptome-wide scope of the ligated cDNA library. Thus, with this library in hand, any RNA of interest can be amplified and subjected to deep 3' terminal profiling (Figure 4). We found that RNase P RNA, which is structurally similar to MRP RNA and also transcribed by RNA polymerase III, had a distribution of additional genomically encoded U's beyond its annotated 3 ' end and virtually no propensity for oligo(A) addition. U3 snoRNA, transcribed by RNA polymerase II [11], was comparatively homogeneous with $99.5 \%$ of reads yielding the annotated 3 ' terminus. In contrast, the RNA component of human telomerase, also transcribed by RNA polymerase II [39], had a greater propensity for oligo(A) addition, with each genomically encoded terminus being more likely to have multiple A's than none
( $n=5$ A's, average mode for endings shown) (Figure 4b, lowest panel).

To assess whether similar 3' termini are captured in other published datasets, we used our bioinformatic pipeline to reanalyze raw poly(A)-depleted RNA sequencing data $[4,40,41]$ and compared our profiles with theirs. Of course, the read depth for any particular RNA was much lower in the published whole-transcriptome datasets, e.g. an average of 1000 reads for MRP RNA per dataset compared with the average of 955,000 obtained here. On the noncoding RNAs analyzed for this study, we found a similar range of genomically encoded sequences with templated and non-templated oligo(U) and oligo(A) additions (Additional file 4: Table S2). Complex 3' ends were also observed at very low abundance, though with properties distinct from those presented in Figure 3. Such endings included attachment of microRNAs, ribosomal RNA fragments and short sense or longer antisense regions of the RNA being analyzed (Additional file 5: Figure S3) and were idiosyncratic to 


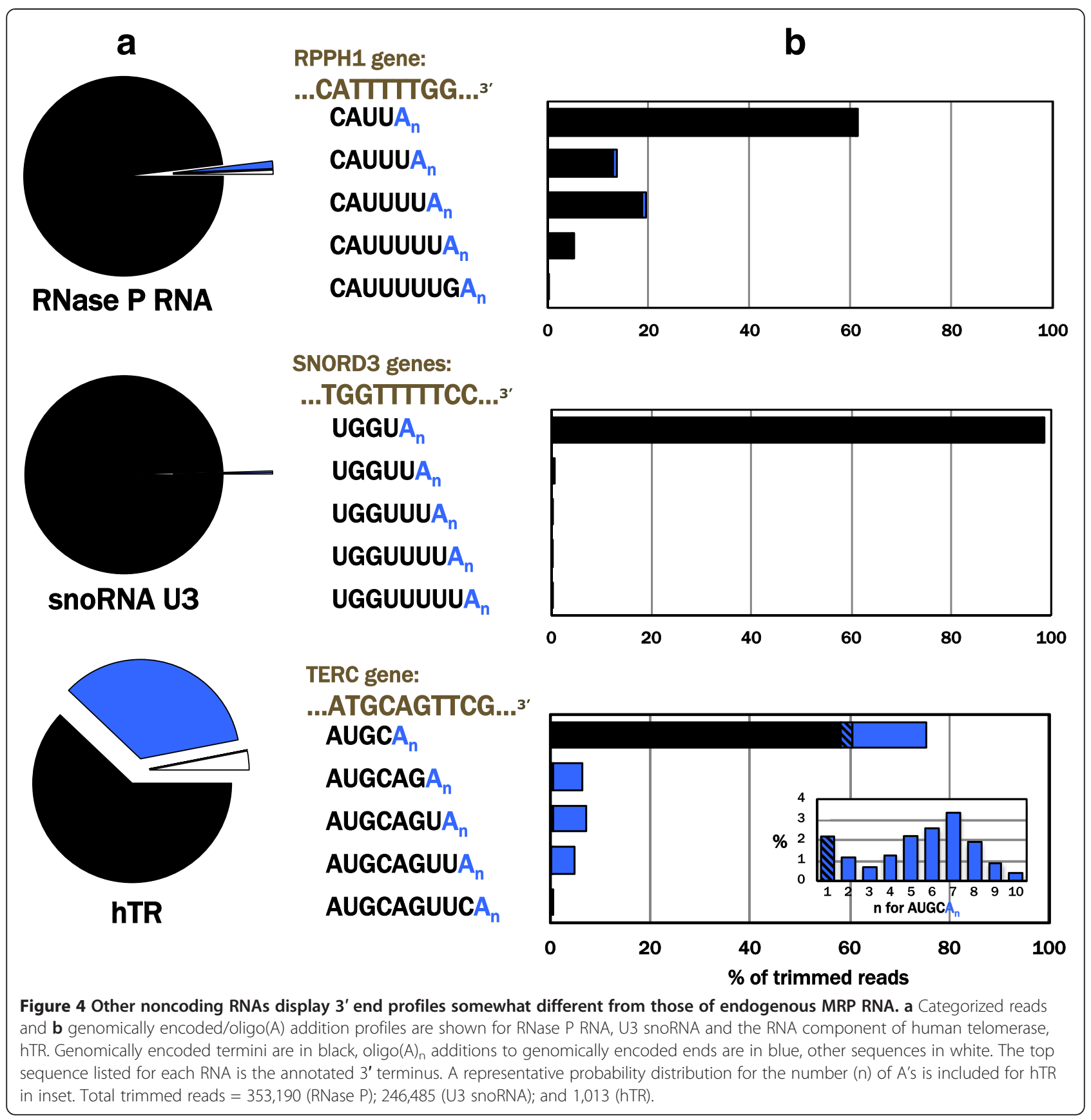

the method of library preparation (Additional file 4: Table S2). Thus, these initially-more-interesting extensions have the hallmarks of artifacts.

\section{Discussion}

The information content of the eukaryotic genome is greatly expanded in the transcriptome through posttranscriptional processing events. Well-studied examples include alternative splicing, RNA editing, and modifications including methylation and pseudouridylation. Recently, Li et al. characterized extensive differences between RNA and DNA sequences within protein coding genes that produce corresponding peptides with sequences that deviate from the genomic template [42]. The RNA 3' end is another site at which post-transcriptional modification occurs and increases the information content of the transcriptome. Here, we analyze MRP RNA and other human noncoding RNAs at a much greater sequencing depth than usual, and find a limited repertoire of sequence additions.

High-throughput sequencing is a powerful technology with continually emerging and illuminating applications. 
The coupling of deep sequencing to the classic RACE technique has provided unprecedented insights into low abundance functional 3' termini heretofore underappreciated [33]. General appendix-tagged cDNA libraries such as the ones produced in this study contain whole transcriptome information that can be specialized (Figure 1c) to amplify any RNA of interest. Even RNAs with nonligatable 3' modifications, such as the $2^{\prime}, 3^{\prime}$-cyclic phosphate on U6 snRNA [43], could be analyzed by comparison of libraries with and without enzymatic 3 '-end deprotection (i.e. $\mathrm{HCl}$ followed by shrimp alkaline phosphatase treatment [44]). A further asset of the RACE sequencing technique is the ability to multiplex this general protocol at several stages, as demonstrated by orthogonal barcoding on the appendices, the control ivt-MRP RNA and the gene-specific RACE primer. Thus, comparison of 3' terminal profiles across fractionated cellular compartments, associated protein partners, time courses or stress conditions enables the regulation of 3 ' terminal extension to be comprehensively defined.

Our 3' RACE sequencing analysis of the steady-state populations of four noncoding RNAs indicates that each RNA has a distinct repertoire of 3' termini. Like MRP RNA, RNase P RNA is transcribed by RNA polymerase III and also has additional uridines beyond the annotated 3 ' end. However, oligoadenylation is much less prominent with RNase $P$ than with MRP RNA. Turning to the RNA polymerase II transcripts, we find U3 snoRNA to have a very homogeneous end. While processing intermediates with additional U's have been observed in reporter expression systems of U3 snoRNA [45], endogenous U3 is often present as a single species [46] consistent with its highly efficient processing. Although previous examination [47] of hTR 3' sequences found the primary terminus to be unadenylated as we did, our data clearly show that a subpopulation of hTR termini have oligo(A) additions. This population was missed by the limited number of clones sequenced in the earlier study and emphasizes the value of deep sequencing.

The oligo(A) additions found in this study are consistent with those added by the TRAMP complex to nuclear RNAs targeted by the RNA exosome (for review see [48]). Along with its primary function in RNA surveillance and decay of both nuclear and mRNAs [49], the exosome processes the 3' termini of some noncoding RNAs (for example [50]). It is plausible that the transcript-specific variations in oligo(A) propensity we observe are correlated with the fraction of each RNA or specific terminus that is bound for exosomal processing or destruction. In that case, the relatively oligo(A)-less U3 snoRNA and RNase P RNA may be at one end of the stability spectrum relative to the highly oligoadenylated hTR (Figure 4). Alternatively, maturation of other snoRNAs has been demonstrated to involve oligoadenylation by noncanonical poly(A) polymerase PAPD5 and trimming by the poly(A) specific ribonuclease PARN [51]. The distribution of oligoadenylations observed on the RNAs in this study may represent intermediates of a similar maturation process.

Much of the initial incentive for this work came from the finding of 3' extensions on MRP RNA by Maida et al. [31], who reported full-length antisense extensions. Although no such extensions were found by our method, long double-stranded RNA might be resistant to amplification and sequencing, so the absence of such sequences in our study cannot be taken as proof that they don't exist. We had observed MRP RNA to have complex 3' endings with potential loopback character akin to those in Figure 3 at low and variable frequency in some early total RNA preparations. Because the abundance of complex extensions on endogenous MRP peaked at $1 \%$ of trimmed reads, hypothetical contamination of non-indexed ivtMRP (with complex extension abundance of 1\%) could not account for all of these sequences. While it is tempting to speculate that the small level of loopback extensions on some preparations of endogenous MRP RNA could be explained by an unidentified variation in cellular growth conditions, we have no further data to support this model.

\section{Conclusion}

While evidence for 3' heterogeneity on MRP RNA was presented as many as 30 years ago [52,53], to our knowledge quantitative profiling has not been previously reported. As an essential RNA demanding tight regulation for cleaving its diversely localized substrates, $3^{\prime}$ terminal extension likely plays a role in MRP RNA control. The distinctive profile of U's and A's on MRP RNA described here provides the necessary framework for testing this hypothesis, prompting further study into the potentially distinct $3^{\prime}$ terminal profiles of RNase MRP subpopulations in the nucleolus and cytoplasm, or associated with different subcomplexes of MRP proteins. The potent ability of 3' RACE sequencing to isolate the terminal sequences of the MRP RNA from the intricate mixture of RNAs present in eukaryotic cells makes it an attractive method to address the functional consequences of these 3 ' termini.

\section{Methods}

\section{In vitro transcription of barcoded MRP RNAs}

MRP RNA (265 nt) was amplified from human genomic DNA using forward primer mrpF1 (Additional file 6: Table S3) containing an EcoRI restriction site followed by T7 promoter and reverse primer mrpR1 containing restriction sites for SapI and BamHI. Agarose gel purified (Qiagen) PCR products were co-digested with EcoRI and BamHI (NEB), re-gel purified and cloned into pUC19 
using T4 DNA ligase (NEB) following the manufacturer's instructions. Insert sequences were confirmed by direct sequencing. Index-containing template for in vitro transcription was produced by PCR in $100 \mu \mathrm{L}$ reactions using $300 \mathrm{ng}$ of MRP plasmid, 1X GC buffer, $400 \mathrm{nM}$ primers (mrpF1, mrp_index1_R2), $2 \mathrm{mM}$ dNTPs, and 5U Phusion polymerase in the following program: $98 \mathrm{C}$ for $2 \mathrm{~min}, 30$ cycles of $98 \mathrm{C}$ for $30 \mathrm{~s}, 55 \mathrm{C}$ for $30 \mathrm{~s}, 72 \mathrm{C}$ for $1 \mathrm{~min}$, and final extension at $72 \mathrm{C}$ for $10 \mathrm{~min}$. Template PCR products were then purified on agarose gels (Qiagen) and the entire eluate was used as template for in vitro transcription in $500 \mu \mathrm{L}$ reactions containing $20 \mathrm{mM} \mathrm{MgCl}$, $5 \mathrm{mM}$ NTPs, $10 \mathrm{mM} \mathrm{DTT}, 4 \mathrm{mg} / \mathrm{mL}$ yeast pyrophosphatase (Sigma) and T7 RNA polymerase. In vitro transcription proceeded for $30 \mathrm{~min}$ at $37 \mathrm{C}$ and was stopped by phenol extraction with ethanol precipitation. Precipitated RNA was treated with 50U RQ1 DNase (Promega) and stopped by phenol extraction with ethanol precipitation according to the manufacturer's instructions. DNase-treated RNA was then PAGE purified and stored in water at $-80 \mathrm{C}$.

\section{Cellular RNA preparation}

HEK293T cells were cultured in DMEM augmented with $10 \%$ FBS and pen/strep. 90\% confluent cells were harvested with trypsin, washed twice with PBS and flash frozen in liquid nitrogen in aliquots of approximately 50 million cells. Cell pellets were extracted for whole cell RNA with Trizol reagent (Ambion) according to the manufacturer's instructions, and quantified for total RNA by absorbance at $260 \mathrm{~nm}$ (via Nanodrop) and MRP RNA by northern blot comparison with ivt-MRP. $50 \mu \mathrm{g}$ whole cell RNA containing approximately 15 ng endogenous MRP with or without $15 \mathrm{ng}$ ivt-MRP was subjected to 50U of RQ1 DNase (Promega) and phenol extracted with ethanol precipitation according to the manufacturer's protocol. Four $5 \mu \mathrm{g}$ aliquots of each sample were then depleted of ribosomal RNA using the RiboZero rRNA Removal Kit (Epicentre), and 800 ng rRNA-depleted sample were subsequently treated with $2 \mathrm{U}$ alkaline phosphatase (Roche) and phenol extracted with ethanol precipitation as per the manufacterer's instructions.

\section{Ligase mediated 3' RACE with deep sequencing}

Library preparation was performed with a protocol similar to methods previously reported [33] with modifications. Pre-ligation reactions $(23 \mu \mathrm{L})$ contained $10 \%$ PEG8000, 125 ng of RQ1, RiboZero, AP-treated whole cell RNA prepared as above and 40 pmol of one RNA appendix from the four listed in Additional file 7: Table S4, so that four separate reactions were carried out for each RNA sample. Pre-ligation reactions were heated to $85 \mathrm{C}$ for $5 \mathrm{~min}$ and immediately transferred to
37C. 10U of T4 RNA Ligase 1 were added to the melted RNAs along with final concentrations of $1 \mathrm{X}$ T4 RNA Ligase Reaction Buffer and $1 \mathrm{mM}$ ATP. Ligation reactions $(30 \mu \mathrm{L})$ were incubated at $37 \mathrm{C}$ for $30 \mathrm{~min}$ and stopped by phenol extraction with ethanol precipitation. Half of each ligation reaction was annealed with 10 pmol RT_primer and $25 \mathrm{nmol}$ dNTPs for $5 \mathrm{~min}$ at $65 \mathrm{C}(35 \mu \mathrm{L}$ reaction volume) and immediately transferred to $55 \mathrm{C}$ for reverse transcription in $50 \mu \mathrm{L}$ reactions performed with $35 \mathrm{mM}$ Tris, $52.5 \mathrm{mM} \mathrm{KCl}, 5 \mathrm{mM} \mathrm{MgCl}{ }^{2}, 10 \mathrm{mM}$ DTT and $200 \mathrm{U}$ of Superscript III (Invitrogen). Reverse transcription lasted $50 \mathrm{~min}$ followed by heat inactivation at $85 \mathrm{C}$ for 5 min. $5 \mu \mathrm{L}$ RT reaction was used as template for RACE and addition of Illumina adapters with 1X GC Buffer, $2 \mathrm{mM} \mathrm{MgCl} 2,10 \%$ DMSO, $400 \mathrm{nM}$ primers X_RACEF/ 3'universal_R1, $400 \mu \mathrm{M}$ dNTPs and 1.25U Phusion polymerase in $25 \mu \mathrm{L}$ final volume with the following program: $98 \mathrm{C}$ for $2 \mathrm{~min}, 18$ cycles of $98 \mathrm{C}$ for $30 \mathrm{~s}, 65 \mathrm{C}$ for $30 \mathrm{~s}, 72 \mathrm{C}$ for $1 \mathrm{~min}$, and final extension at $72 \mathrm{C}$ for $10 \mathrm{~min}$. The entire RACE reaction was loaded on $2.5 \%$ agarose gels and amplicons of $\sim 150-600$ bp were excised for purification (Qiagen). Purified RACE products $(30 \mu \mathrm{L})$ were used as template for library amplification in $100 \mu \mathrm{L}$ reactions containing $1 \mathrm{X}$ HF Buffer, $2 \mathrm{mM} \mathrm{MgCl}{ }^{2}, 400 \mathrm{nM}$ primers Gen_primer-F2/Gen_primer-R2, $400 \mu \mathrm{M}$ dNTPs and $5 \mathrm{U}$ Phusion polymerase with the following program: $98 \mathrm{C}$ for $2 \mathrm{~min}, 14$ cycles of $98 \mathrm{C}$ for $30 \mathrm{~s}, 58 \mathrm{C}$ for $30 \mathrm{~s}, 72 \mathrm{C}$ for 1 $\mathrm{min}$, and final extension at $72 \mathrm{C}$ for $10 \mathrm{~min}$. These nested amplicons were subjected to PCR cleanup (Qiagen), quantified by Qubit and Bioanalyzer, diluted to $2 \mathrm{nM}$ in $10 \mathrm{mM}$ Tris- $\mathrm{HCl}, \mathrm{pH} 8.5$, and combined for sequencing. 3-3.2 pM pooled libraries containing 30\% phiX control V3 (Illumina) were run on the Illumina MiSeq following the manufacturer's instructions.

\section{Data analysis}

300 basepair reads were assessed for quality using FASTX software and trimmed from adapters to isolate relevant insert content (Figure 1f) using a custom python script. Briefly, reads containing both a perfect appendix sequence and perfect search primer (Additional file 1: Table S1) for the RNA of interest were selected for processing, and this set was further trimmed to yield reads containing the $5^{\prime}$ end of the search primer through the $5^{\prime}$ end of the appendix (indicated region in Figure 1f). Identical trimmed reads were then collapsed to assess the abundance of each terminus and the depth of variation in 3 ' terminal sequences.

\section{Additional files}

Additional file 1: Table S1. Search primers for bioinformatics assessment of $3^{\prime}$ ends. 

Additional file 2: Figure S1. 3' termini of MRP RNA from human K562
cells.

Additional file 3: Figure S2. Northern analysis of ivt-MRP and total RNA from HEK293T cells.

Additional file 4: Table S2. Summary of 3' termini from publicly available datasets $[4,40,41]$.

Additional file 5: Figure S3. Examples of complex "extensions" found in publically available datasets.

Additional file 6: Table S3. Primers used in this study.

Additional file 7: Table S4. Appendix RNA oligonucleotide sequences.

\section{Competing interests}

The authors declare they have no competing interests.

\section{Authors' contributions}

KCG and TRC conceived the study and wrote the manuscript. KCG carried out the experiments and bioinformatics analysis. All authors read and approved the final manuscript for publication.

\section{Acknowledgements}

The authors would like to thank Elaine Podell, Jim Goodrich, Jennifer Kugel, Roy Parker, Jim Huntley, Rui Yi and Sumit Borah (all at the University of Colorado, Boulder) for reagents, critical discussions, scientific and technical advice. K.C.G. was supported by the NIH Molecular Biophysics Training Scholarship (T32 GM-065103). T.R.C. is an investigator of the Howard Hughes Medical Institute. This work was supported by NIH grant R01 GM099705.

Received: 2 August 2013 Accepted: 13 September 2013 Published: 21 September 2013

\section{References}

1. Jones MR, Quinton LJ, Blahna MT, Neilson JR, Fu S, Ivanov AR, Wolf DA, Mizgerd JP: Zcchc11-dependent uridylation of microRNA directs cytokine expression. Nat Cell Biol 2009, 11:1157-1163.

2. Chiang HR, Schoenfeld LW, Ruby JG, Auyeung VC, Spies N, Baek D, Johnston WK, Russ C, Luo S, Babiarz JE, et al: Mammalian microRNAs: experimental evaluation of novel and previously annotated genes. Genes Dev 2010, 24:992-1009.

3. Heo I, Ha M, Lim J, Yoon MJ, Park JE, Kwon SC, Chang H, Kim VN: Mono-uridylation of pre-microRNA as a key step in the biogenesis of group II let-7 microRNAs. Cell 2012, 151:521-532.

4. Choi YS, Patena W, Leavitt AD, McManus MT: Widespread RNA 3'-end oligouridylation in mammals. RNA 2012, 18:394-401.

5. Chen Y, Sinha K, Perumal K, Reddy R: Effect of $3^{\prime}$ terminal adenylic acid residue on the uridylation of human small RNAs in vitro and in frog oocytes. RNA 2000, 6:1277-1288.

6. Katoh T, Sakaguchi Y, Miyauchi K, Suzuki T, Kashiwabara S, Baba T, Suzuki T: Selective stabilization of mammalian microRNAs by 3' adenylation mediated by the cytoplasmic poly(A) polymerase GLD-2. Genes Dev 2009, 23:433-438

7. Burroughs AM, Ando Y, de Hoon MJ, Tomaru Y, Nishibu T, Ukekawa R, Funakoshi T, Kurokawa T, Suzuki H, Hayashizaki Y, Daub CO: A comprehensive survey of $3^{\prime}$ animal miRNA modification events and a possible role for $3^{\prime}$ adenylation in modulating miRNA targeting effectiveness. Genome Res 2010, 20:1398-1410.

8. Lund E, Dahlberg JE: Cyclic 2',3'-phosphates and nontemplated nucleotides at the $3^{\prime}$ end of spliceosomal U6 small nuclear RNA's. Science 1992, 255:327-330.

9. Grzechnik P, Kufel J: Polyadenylation linked to transcription termination directs the processing of snoRNA precursors in yeast. Mol Cell 2008, 32:247-258

10. van Hoof $A$, Lennertz $P$, Parker $R$ : Yeast exosome mutants accumulate 3 '-extended polyadenylated forms of U4 small Nuclear RNA and small nucleolar RNAs. Mol Cell Biol 2000, 20:441-452.

11. Kiss $T$, Fayet $E$, Jady BE, Richard $P$, Weber M: Biogenesis and intranuclear trafficking of human box C/D and H/ACA RNPs. Cold Spring Harb Symp Quant Biol 2006, 71:407-417.
12. Yuan $Y$, Reddy R: 5' Flanking sequences of human MRP/7-2 RNA gene are required and sufficient for the transcription by RNA polymerase III. Biochim Biophys Acta 1991, 1089:33-39.

13. Shadel GS, Buckenmeyer GA, Clayton DA, Schmitt ME: Mutational analysis of the RNA component of Saccharomyces cerevisiae RNase MRP reveals distinct nuclear phenotypes. Gene 2000, 245:175-184.

14. Ridanpää M, van Eenennaam H, Pelin K, Chadwick R, Johnson C, Yuan B, van Venrooij W, Pruijn G, Salmela R, Rockas S, Mäkitie O, Kaitila I, de la Chapelle A: Mutations in the RNA component of RNase MRP cause a pleiotropic human disease, cartilage-hair hypoplasia. Cell 2001, 104:195-203.

15. Welting TJ, Kikkert BJ, van Venrooij WJ, Pruijn GJ: Differential association of protein subunits with the human RNase MRP and RNase $\mathrm{P}$ complexes. RNA 2006, 12:1373-1382.

16. Lopez MD, Rosenblad MA, Samuelsson T: Conserved and variable domains of RNase MRP RNA. RNA Biol 2009, 6:208-220.

17. Chang DD, Clayton DA: A novel endoribonuclease cleaves at a priming site of mouse mitochondrial DNA replication. EMBO J 1987, 6:409-417.

18. Chang DD, Clayton DA: A Mammalian mitochondrial RNA processing activity contains nucleus-encoded RNA. Science 1987, 235:1178-1184.

19. Schmitt ME, Clayton DA: Nuclear RNase MRP is required for correct processing of pre-5.8S rRNA in Saccharomyces cerevisiae. Mol Cell Biol 1993, 13:7935-7941.

20. Lindahl L, Bommankanti A, Li X, Hayden L, Jones A, Khan M, Oni T, Zengel JM: RNase MRP is required for entry of $35 \mathrm{~S}$ precursor rRNA into the canonical processing pathway. RNA 2009, 15:1407-1416.

21. Cai T, Aulds J, Gill T, Cerio M, Schmitt ME: The saccharomyces cerevisiae RNase mitochondrial RNA processing is critical for cell cycle progression at the end of mitosis. Genetics 2002, 161:1029-1042.

22. Gill T, Cai T, Aulds J, Wierzbicki S, Schmitt ME: RNase MRP Cleaves the CLB2 mRNA to promote cell cycle progression: novel method of mRNA degradation. Mol Cell Biol 2004, 24:945-953.

23. Jaag HM, Lu Q, Schmitt ME, Nagy PD: Role of RNase MRP in viral RNA degradation and RNA recombination. J Virol 2011, 85:243-253.

24. Mattijssen S, Hinson ER, Onnekink C, Hermanns P, Zabel B, Cresswell P, Pruijn GJ: Viperin mRNA is a novel target for the human RNase MRP/ RNase P endoribonuclease. Cell Mol Life Sci 2011, 68:2469-2480.

25. Kiss T, Marshallsay C, Filipowicz W: 7-2/MRP RNAs in plant and mammalian cells: association with higher order structures in the nucleolus. EMBO J 1992, 11:3737-3746.

26. Jacobson MR, Cao L, Wang Y, Pederson T: Dynamic localization of RNase MRP RNA in the nucleolus observed by fluorescent RNA cytochemistry in living cells. J Cell Biol 1995, 131:1649-1658.

27. Gill T, Aulds J, Schmitt ME: A specialized processing body that is temporally and asymmetrically regulated during the cell cycle in Saccharomyces cerevisiae. J Cell Biol 2006, 173:35-45.

28. Li K, Smagula CS, Parsons WJ, Richardson JA, Gonzalez M, Hagler HK, Williams RS: Subcellular partitioning of MRP RNA assessed by ultrastructural and biochemical analysis. J Cell Biology 1994, 124:871-882.

29. Kiss T, Filipowicz W: Evidence against a mitochondrial location of the 7-2/MRP RNA in mammalian cells. Cell 1992, 70:11-16.

30. Rosenblad MA, Lopez MD, Piccinelli P, Samuelsson T: Inventory and analysis of the protein subunits of the ribonucleases $P$ and MRP provides further evidence of homology between the yeast and human enzymes. Nucleic Acids Res 2006, 34:5145-5156.

31. Maida $Y$, Yasukawa M, Furuuchi M, Lassmann T, Possemato R, Okamoto N, Kasim V, Hayashizaki Y, Hahn WC, Masutomi K: An RNA-dependent RNA polymerase formed by TERT and the RMRP RNA. Nature 2009, 461:230-235.

32. Zhuang F, Fuchs RT, Sun Z, Zheng Y, Robb GB: Structural bias in T4 RNA ligase-mediated 3'-adapter ligation. Nucleic Acids Res 2012, 40:e54.

33. Wilusz JE, Whipple JM, Phizicky EM, Sharp PA: tRNAs marked with CCACCA are targeted for degradation. Science 2011, 334:817-821.

34. Newman MA, Mani V, Hammond SM: Deep sequencing of microRNA precursors reveals extensive 3 ' end modification. RNA 2011, 17:1795-1803.

35. Hafner M, Renwick N, Brown M, Mihailovic A, Holoch D, Lin C, Pena JT, Nusbaum JD, Morozov P, Ludwig J, et al: RNA-ligase-dependent biases in miRNA representation in deep-sequenced small RNA CDNA libraries. RNA 2011, 17:1697-1712 
36. Scott DD, Norbury CJ: RNA decay via 3' uridylation. Biochim Biophys Acta 1829, 2013:654-665.

37. Cazenave C, Uhlenbeck OC: RNA template-directed RNA synthesis by $T 7$ RNA polymerase. Proc Natl Acad Sci USA 1994, 91:6972-6976.

38. Wagner SD, Yakovchuk P, Gilman B, Ponicsan SL, Drullinger LF, Kugel JF, Goodrich JA: RNA polymerase II acts as an RNA-dependent RNA polymerase to extend and destabilize a non-coding RNA. EMBO J 2013, 32:781-790.

39. Mitchell JR, Cheng J, Collins K: A box H/ACA small nucleolar RNA-like domain at the human telomerase RNA 3' end. Mol Cell Biol 1999, 19:567-576.

40. Derrien T, Johnson R, Bussotti G, Tanzer A, Djebali S, Tilgner H, Guernec G, Martin D, Merkel A, Knowles DG, et al: The GENCODE v7 catalog of human long noncoding RNAs: analysis of their gene structure, evolution, and expression. Genome Res 2012, 22:1775-1789.

41. Tilgner H, Knowles DG, Johnson R, Davis CA, Chakrabortty S, Djebali S, Curado J, Snyder M, Gingeras TR, Guigo R: Deep sequencing of subcellular RNA fractions shows splicing to be predominantly co-transcriptional in the human genome but inefficient for IncRNAs. Genome Res 2012, 22:1616-1625.

42. Li M, Wang IX, Li Y, Bruzel A, Richards AL, Toung JM, Cheung VG: Widespread RNA and DNA sequence differences in the human transcriptome. Science 2011, 333:53-58

43. Shchepachev V, Wischnewski H, Missiaglia E, Soneson C, Azzalin CM: Mpn1, mutated in poikiloderma with neutropenia protein 1 , is a conserved 3'-to-5' RNA exonuclease processing U6 small nuclear RNA. Cell Rep 2012, 2:855-865.

44. Mroczek S, Krwawicz J, Kutner J, Lazniewski M, Kucinski I, Ginalski K, Dziembowski A: C16orf57, a gene mutated in poikiloderma with neutropenia, encodes a putative phosphodiesterase responsible for the U6 snRNA 3' end modification. Genes Dev 2012, 26:1911-1925.

45. Verheggen C, Lafontaine DL, Samarsky D, Mouaikel J, Blanchard JM, Bordonne R, Bertrand E: Mammalian and yeast U3 snoRNPs are matured in specific and related nuclear compartments. EMBO J 2002, 21:2736-2745

46. Boulon S, Marmier-Gourrier N, Pradet-Balade B, Wurth L, Verheggen C, Jady BE, Rothe B, Pescia C, Robert MC, Kiss T, et al: The Hsp90 chaperone controls the biogenesis of L7Ae RNPs through conserved machinery. J Cell Biol 2008, 180:579-595.

47. Zaug AJ, Lingner J, Cech TR: Method for determining RNA 3' ends and application to human telomerase RNA. Nucleic Acids Res 1996, 24:532-533.

48. Schmid $\mathrm{M}$, Jensen $\mathrm{TH}$ : The exosome: a multipurpose RNA-decay machine. Trends Biochem Sci 2008, 33:501-510.

49. Schneider C, Kudla G, Wlotzka W, Tuck A, Tollervey D: Transcriptome-wide analysis of exosome targets. Mol Cell 2012, 48:422-433.

50. Schilders G, Raijmakers R, Raats JM, Pruijn GJ: MPP6 is an exosomeassociated RNA-binding protein involved in 5.8S rRNA maturation. Nucleic Acids Res 2005, 33:6795-6804.

51. Berndt H, Harnisch C, Rammelt C, Stohr N, Zirkel A, Dohm JC, Himmelbauer $\mathrm{H}$, Tavanez JP, Huttelmaier S, Wahle E: Maturation of mammalian H/ACA box snoRNAs: PAPD5-dependent adenylation and PARN-dependent trimming. RNA 2012, 18:958-972.

52. Reddy $R$, Tan EM, Henning D, Nohga K, Busch $H$ : Detection of a nucleolar 7-2 ribonucleoprotein and a cytoplasmic 8-2 ribonucleoprotein with autoantibodies from patients with scleroderma. J Biol Chem 1983, 258:1383-1386.

53. Hashimoto C, Steitz JA: Sequential association of nucleolar 7-2 RNA with two different autoantigen. J Biol Chem 1983, 258:1379-1382.

doi:10.1186/1471-2199-14-23

Cite this article as: Goldfarb and Cech: $3^{\prime}$ terminal diversity of MRP RNA and other human noncoding RNAs revealed by deep sequencing. BMC Molecular Biology 2013 14:23.

\section{Submit your next manuscript to BioMed Central and take full advantage of:}

- Convenient online submission

- Thorough peer review

- No space constraints or color figure charges

- Immediate publication on acceptance

- Inclusion in PubMed, CAS, Scopus and Google Scholar

- Research which is freely available for redistribution

Submit your manuscript at www.biomedcentral.com/submit
C Biomed Central 